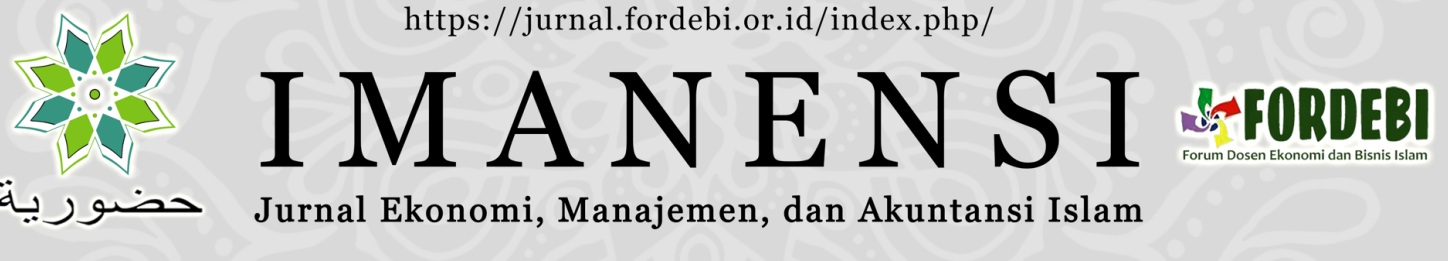

\title{
MENTAL ACCOUNTING SEBAGAI BENTUK PRAKTIK AKUNTANSI PINJAMAN DANA
}

\author{
Ajeng Purwandani $a, 1$ *, Aji dedi Mulawarman ${ }^{b, 2}$ \\ $a, b$ Universitas Brawijaya J1. MT Haryono 165, Malang, 65145, Indonesia. \\ 1ajengpurwandani08@gmail.com; 2 ajidedim@gmail.com* \\ *Corresponding author
}

\begin{tabular}{|c|c|}
\hline INFO ARTIKEL & Abstrak: Mental Accounting \\
\hline IMANENSI & Akuntansi Pinjaman Dana. Penelitian ini bertujuan untuk \\
\hline Volume 6 & pinjaman dana oleh bank tithil ke \\
\hline Nomor 1 & pedagang di Pasar Singosari. \\
\hline Halaman 43-54 & dijadikan alat untuk meneliti praktik akuntansi pinjaman dana \\
\hline Malang, Maret 2021 & dengan informan adalah pemilik dana (bank tithil) dan \\
\hline $\begin{array}{l}\text { ISSN: } 2339-1847 \\
\text {-ISSN } \cdot 2683-9968\end{array}$ & pedagang pasar. Hasil penelitian menunjukkan bahwa terdapat \\
\hline e-ISSN: 2683-9968 & dua bentuk penyaluran dana pinjaman, yaitu sistem pinjaman \\
\hline Kronologi Artikel: & biasa dan sistem arisan. Praktik akuntansi pinjaman dana bank \\
\hline Tanggal Masuk: & menggunakan mental accounting, yaitu membuat catatan \\
\hline 14 Desember 2020 & atau hanya mengingat transaksi. \\
\hline
\end{tabular}

Tanggal Revisi:

12 Maret 2021

Tanggal Diterima:

16 Maret 2021

Kata Kunci:

Arisan;

Etnometodologi;

Pedagang pasar;

Rentenir;

Keywords:

Arisan;

Ethnometodology

Market traders;

Moneylenders;

\begin{abstract}
Abstrak: Mental Accounting Sebagai Bentuk Praktik pedagang di Pasar Singosari. Pendekatan etnometodologi dijadikan alat untuk meneliti praktik akuntansi pinjaman dana engan informan adalah pemilik dana (bank tithil) dan dua bentuk penyaluran dana pinjaman, yaitu sistem pinjaman tithil menggunakan mental accounting, yaitu membuat catatan kecil di kertas atau hanya mengingat transaksi.
\end{abstract}

\begin{abstract}
Mental Accounting as a Form of Loan Funding Accounting Practices. This study aims to find out the practice of lending by tithil banks to traders in Singosari Market. The ethnometodological approach is used as a tool to examine the accounting practices of loan funds with informants being the owner of the funds (tithil bank) and traders. The results showed that there were two forms of distribution of loan funds, namely the regular loan system and the arisan system. The accounting practice of tithil bank loan funds uses mental accounting, which is making small notes on paper or just remembering transactions.
\end{abstract}

Disitasi sebagai: Purwandani, A., dan Mulawarman, A.D. (2021). Mental Accounting Sebagai Bentuk Praktik Akuntansi Pinjaman Dana. IMANENSI: Jurnal Ekonomi, Manajemen, dan Akuntansi Islam, 6(1), 55-64. https://doi.org/10.34202/imanensi.6.1.2021.55-64.

\section{PENDAHULUAN}

Underground Economy merupakan kegiatan ekonomi yang tidak lepas dari sebagian besar negara dan pasti ada dalam kegiatan manusia. Scheineider dan Enste (2000) menyatakan bahwa Underground economy yaitu kegiatan-kegiatan ekonomi yang dilakukan baik secara legal ataupun illegal yang terlewat dari perhitungan Produk Domestik Bruto (PDB) dapat dikenal dengan nama lain yaitu unofficially economy atau black economy yang saat ini telah menjadi isu global. Kegiatan bawah tanah tersebut kegiatan yang tidak tercatat oleh pemerintah, kemudian akan 
menciptakan kerugian untuk negara. Underground economy pun dapat terjadi di kalangan masyarakat menengah ke bawah hingga menengah ke atas.

Manusia pada hakekatnya memiliki keinginan untuk mendapatkan jaminan ekonomi. Dengan sistem yang berjalan, seluruh masyarakat akan terikat dengan aturan yang telah dibuat. Sehingga masyarakat dalam memenuhi kebutuhannya harus sesuai dengan sistem yang ada. Pencapaian dalam sistem ini dibutuhkan penjaminan yaitu sebagai jembatan yang menghubungkan pemecahan masalah ekonomi sekarang ini. Dalam transaksi ini yaitu pinjaman dana sebagai media yang cepat untuk sistem perekonomian di masyarakat.

Pinjaman dana yang cepat ini diartikan sebagai seseorang atau lembaga yang memiliki harta yang lebih dari cukup secara finansial kemudian, hartanya dapat dijadikan alat pinjaman untuk masyarakat secara luas yang sedang membutuhkan uang untuk modal dalam mengembangkan usahanya yang dapat bersifat pribadi maupun kelembagaan. Salah satunya modal yang disalurkan oleh kredit informal. Umar (2000) menjabarkan bahwa modal merupakan faktor produksi yang mempunyai pengaruh kuat dalam mendapatkan produktivitas atau output, secara makro modal merupakan pendorong besar untuk meningkatkan investasi baik secara langsung pada proses produksi maupun dalam prasarana produksi, sehingga mampu mendorong kenaikan produktivitas dan output. Modal meliputi semua barang yang diproduksi tidak untuk dikonsumsi melainkan untuk produksi lebih lanjut. Chaudhry (2014) menyatakan bahwa barang-barang yang dinyatakan modal sebagai berikut; mesin, peralatan, alat-alat pengangkutan, proyek irigasi seperti kanal dan dam, persediaan bahan mentah, uang tunai yang ditanamkan di perusahaan, dan lain sebagainya.

Perlakuan akuntansi untuk pengakuan, pengukuran, penyajian, dan pengungkapan yang dilakukan oleh pedagang, rentenir, dan bandar dengan pemahaman masing-masing. Kegiatan tersebut dikategorikan sebagai mental accounting. Rospitadewi dan Efferin (2017) menyatakan bahwa teori mental accounting sama dengan sebuah perusahaan, seseorang akan mencatat dan mengkategorikan pengeluaran ke dalam akun-akun sesuai dengan pemahaman mereka. Penelitian ini membahas akuntansi pinjaman dana yang dilakukan oleh pemilik dana dan pedagang di Pasar Singosari.

Penelitian mengenai pedagang dan rentenir sudah banyak dilakukan. Hasil penelitian Khairi (2018) menunjukkan alasan pedagang meminjam kepada rentenir dikarenakan proses peminjaman uang yang cepat, mudah, bermodalkan kepercayaan, tidak harus memberikan jaminan, nominal pinjaman tidak tergolong besar, dapat langsung menerima pinjaman uang dan karena keterpaksaan. Aulia (2017) menyatakan di pasar besar Palangkaraya dalam praktiknya rentenir biasa ada yang datang langsung menawarkan pinjaman kepada para pedagang di pasar besar ada juga yang mendatangi langsung karena sudah mengenalnya. Nurhidayati (2012), Perbedaan penelitian ini dengan penelitian terdahulu terdapat pada tujuan penelitian yang dalam penelitian ini mencari perlakuan akuntansi terhadap pengakuan, pengukuran, penyajian, dan pengungkapan dari pedagang, rentenir, dan bandar. Kemudian, perbedaan terdapat pada alat analisisnya, penelitian ini menggunakan penelitian kualitatif dengan pendekatan etnometodologi. Serta tempat penelitian yang akan dilakukan di Pasar Singosari, Kabupaten Malang.

\section{METODE}

Metode penelitian menggunakan metode kualitatif dengan pendekatan etnometodologi di Pasar Singosari, Kabupaten Malang selama bulan April sampai Agustus 2020. Sumber data diperoleh dari wawancara dengan sebelas informan yaitu 5 orang pedagang yang memakai jasa pinjaman biasa, 3 orang pedagang 
memakai jasa arisan, 2 orang rentenir dari pinjaman biasa, dan 1 orang bandar arisan. Penelitian ini bertujuan untuk mengetahui akuntansi pinjaman dana bank tithil yang ada di Pasar Singosari.

Teknik Pengumpulan Data merupakan cara yang digunakan untuk mendapatkan data penelitian, proses cara memperoleh data tersebut dilakukan dengan cara penelitian lapangan yaitu observatif non partisipan, wawancara, dan dokumentasi di Pasar Singosari. Teknik Analisis Data yang dilakukan penulis dengan tujuan untuk memahami proses akuntansi penyaluran modal bank tithil. Analisis dilakukan berdasarkan data yang telah diperoleh dari informan. Untuk proses pelaksanaannya sendiri dilakukan pada saat peneliti berada di Pasar Singosari dengan melakukan tahapan pengumpulan data dengan cara analisis gesture dan percakapan pada saat terjadinya wawancara. Untuk mendukung analisis gesture dan percakapan tersebut, terdapat tiga cara dalam penelitian Moeleong (2007; 104), yaitu: Reduksi data, Penyajian data, dan Menarik Kesimpulan.

Keabsahan data menggunakan cakupan triangulasi yang dipaparkan oleh Moleong $(2001 ; 179)$ yaitu membandingkan yang dikatakan semua informan tentang situasi penelitian sepanjang waktu, membandingkan data hasil pengamatan dengan data hasil wawancara, membandingkan hasil wawancara dengan isi suatu dokumen yang berkaitan, membandingkan apa yang dikatakan orang depan umum dengan apa yang dikatakannya secara pribadi, membandingkan keadaan dan perspektif seseorang berbagai pendapat dan pandangan orang seperti rakyat biasa, orang berpendidikan, dan orang pemerintah.

\section{HASIL DAN PEMBAHASAN}

\subsection{Praktik Pinjaman Dana oleh Bank Tithil1 di Pasar Singosari}

Praktik pinjaman dana bank tithil di Pasar Singosari dibagi menjadi dua yaitu, sistem pinjaman biasa dan sistem arisan. Seperti yang terjadi di lapangan 8 pedagang yang melakukan pinjaman dana bank tithil, diantaranya 5 pedagang yang melakukan pinjaman dana bank tithil sistem pinjaman biasa yaitu Mba Siti, Ibu Sumiati, Ibu Tini, Pak Rahmat, dan Mba Nur. Kemudian 3 pedagang yang melakukan pinjaman dana bank tithil sistem arisan yaitu Bu Nia, Ibu Tantri, dan Ibu Salama. Pada awal pinjam meminjam dana bank tithil dalam sistem pinjaman biasa pedagang ada yang langsung mendatangi atau menghubungi rentenir melalui telepon karena sudah saling mengenal, ada juga yang mendapatkan selebaran kertas kecil isi didalamnya nomor whatsAap dari rentenir.

Pedagang menyampaikan keinginannya untuk meminjam dana pada rentenir ketika bertemu. Pada saat bertatap muka pedagang dan rentenir mulai berinteraksi untuk merundingkan banyak hal mulai dari jumlah dana yang ingin dipinjam, berapa lama untuk tempo pembayaran, berapa jumlah angsuran yang harus dibayarkan setiap hari sesuai dengan ketetapan harinya, berapa jumlah uang yang dikembalikan, jika ada jaminan berupa barang yang akan ditarik oleh rentenir dari pedagang termasuk ada pembicaraan berbeda lagi ketika pedagang tidak dapat membayar angsuran. Setelah semuanya sudah selesai maka rentenir dapat memberikan dana tersebut pada pedagang.

Bank tithil sistem arisan pada awalnya terjadi karena pedagang mengetahui sistem arisan tersebut dari temannya yang mengajak untuk gabung, ada juga bandar yang keliling di Pasar Singosari untuk menawarkan sistem arisan tersebut langsung pada pedagang. Setelah bertemu dan bertatap muka pedagang dapat menyampaikan

\footnotetext{
${ }^{1}$ Bank titil seringkali identik dengan rentenir atau sering juga disebut tengkulak (terutama di pedesaan) adalah orang yang memberi pinjaman uang tidak resmi atau resmi dengan bunga tinggi. Pinjaman ini tidak diberikan melalui badan resmi, misalnya bank (Wikipedia)
} 
keinginannya untuk bergabung di arisan tersebut. Mereka merundingkan banyak hal setelah bandar menyampaikan peraturan-peraturan dalam arisan. Setelah selesai baru bandar memulai sistem arisan tersebut.

Tabel 1 Ringkasan Analisis dalam Praktik Pinjaman Dana Bank Tithil

\begin{tabular}{|c|c|c|c|}
\hline No. & Indeksikalitas & Rafleksivitas & Aksi Kontekstual \\
\hline 1. & Bank Thitil & $\begin{array}{l}\text { Usaha pinjaman dana yang dilakukan } \\
\text { oleh perseorangan dengan cara } \\
\text { keliling disuatu tempat. }\end{array}$ & - Bank Keliling \\
\hline 2. & Rentenir & $\begin{array}{l}\text { Orang yang melakukan praktik } \\
\text { penyaluran peminjaman dana dengan } \\
\text { cara bank keliling atau disebut } \\
\text { dengan bank thitil. }\end{array}$ & $\begin{array}{ll}\text { - } & \text { Melalui WhatsAap } \\
\text { - } & \text { Melalui } \\
& \text { Pertemanan }\end{array}$ \\
\hline 3. & Bunga & $\begin{array}{l}\text { Bunga atau riba yang menjadi } \\
\text { tambahan dana ketika meminjam } \\
\text { dana pada bank thitil. }\end{array}$ & $\begin{array}{ll}\text { - Sudah sama tahu } \\
\text { - Kesepakatan } \\
\text { bersama }\end{array}$ \\
\hline 4. & Teman saya & $\begin{array}{l}\text { Teman merupakan sebagai alasan } \\
\text { yang paling cepat untuk meminjam } \\
\text { dana dan dijadikan sebagai } \\
\text { kepercayaan. }\end{array}$ & $\begin{array}{ll}\text { - } & \text { Berbicara secara } \\
\text { langsung } \\
\text { - } \quad \text { Melalui telepon }\end{array}$ \\
\hline 5. & Butuh & $\begin{array}{l}\text { Butuh merupakan sebagai alasan } \\
\text { untuk meminjam dana kepada } \\
\text { rentenir. }\end{array}$ & $\begin{array}{l}\text { - Melalui telepon } \\
\text { secara langsung }\end{array}$ \\
\hline 6. & Ibunya & $\begin{array}{lcr}\begin{array}{l}\text { Seseorang } \\
\text { meminjamkan } \\
\text { pedagang. }\end{array} & \begin{array}{c}\text { (rentenir) } \\
\text { dana }\end{array} & \begin{array}{r}\text { yang } \\
\text { kepada }\end{array} \\
\end{array}$ & $\begin{array}{l}\text { - Melalui telepon } \\
\text { secara langsung }\end{array}$ \\
\hline 7. & Ibu itu & $\begin{array}{lcr}\begin{array}{l}\text { Seseorang } \\
\text { meminjamkan } \\
\text { pedagang. }\end{array} & \begin{array}{c}\text { (rentenir) } \\
\text { dana }\end{array} & \begin{array}{r}\text { yang } \\
\text { kepada }\end{array} \\
\end{array}$ & $\begin{array}{ll}\text { - } & \text { Melalui telepon } \\
\text { secara langsung }\end{array}$ \\
\hline 8. & Ambil oven kue & $\begin{array}{l}\text { Jaminan yang diambil oleh rentenir, } \\
\text { pada saat pembayaran menunggak. }\end{array}$ & $\begin{array}{l}\text { - Kesepakatan } \\
\text { bersama }\end{array}$ \\
\hline 9. & $\begin{array}{l}\text { Sama orang } \\
\text { dikenal saja }\end{array}$ & $\begin{array}{l}\text { Salah satu syarat ketika, rentenir } \\
\text { memberikan pinjaman dana kepada } \\
\text { pedagang. }\end{array}$ & $\begin{array}{ll}\text { - } & \text { Bertemu secara } \\
\text { langsung } \\
\text { - } \quad \text { Melalui telepon } \\
\end{array}$ \\
\hline 10. & Minjem & $\begin{array}{l}\text { Kata yang sering digunakan pedagang } \\
\text { ketika ingin meminjam dana kepada } \\
\text { rentenir. }\end{array}$ & $\begin{array}{ll}\text { - } & \text { Bertemu secara } \\
\text { langsung } \\
\text { - } & \text { Melalui telepon } \\
\end{array}$ \\
\hline 11. & Bunganya & $\begin{array}{l}\text { Bunga atau riba yang menjadi } \\
\text { tambahan dana ketika meminjam } \\
\text { dana pada bank tithil. }\end{array}$ & $\begin{array}{ll}\text { - } & \text { Sudah sama tau } \\
\text { - } & \text { Kesepakatan } \\
\text { bersama }\end{array}$ \\
\hline 12. & Bandar & $\begin{array}{l}\text { Seseorang yang menjadi pengendali } \\
\text { dari pinjaman yang ditutupi oleh } \\
\text { arisan. }\end{array}$ & $\begin{array}{l}\text { Mendatangi } \\
\text { pedagang } \\
\text { lapaknya } \\
\end{array}$ \\
\hline 13. & Arisan & $\begin{array}{l}\text { Bank tithil yang ditutupi oleh arisan, } \\
\text { dilakukan dengan cara menagih } \\
\text { angsuran setiap hari. }\end{array}$ & $\begin{array}{l}\text { Menabung setiap } \\
\text { hari }\end{array}$ \\
\hline
\end{tabular}

Transaksi antara pedagang, rentenir, dan bandar pun terjalin di pasar karena pasar merupakan tempat yang banyak dilalui oleh orang-orang yang sekadar hanya untuk melihat atau melakukan transaksi jual beli. Pinjam meminjam yang berada di Pasar Singosari termasuk ke dalam pasar uang yana mana pasar uang merupakan penyedia layanan jasa keuangan kurang dari satu tahun dan tidak memiliki tempat secara fisik seperti, pasar modal. Untuk dana yang diberikan rentenir dalam bank tithil pinjaman biasa yaitu dalam bentuk utang kepada pedagang dihasilkan dari modal sendiri yang berasal dari pembayaran pinjaman angsuran beserta bunga. Kemudian, untuk bank tithil sistem arisan tergolong dari modal sendiri yang diperoleh dari tabungan masing-masing pedagang yang dibayar setiap hari sesuai kesepakatan dari bandar. 
Peneliti melakukan analisis indeksikalitas, kemudian dilakukan studi refleksivitas dengan cara memberi makna atau rasionalisasi suatu ekspresi dari informan pada saat wawancara, dan selanjutnya melihat aksi kontekstual informan dalam penelitian ini di Pasar Singosari. Tabel 1 menunjukkan bahwa praktik pinjaman dana bank tithil di Pasar Singosari terletak pada unsur saling mengenal. Rentenir dalam sistem pinjaman biasa lebih mengedepankan unsur saling mengenal. Untuk bandar dalam sistem arisan juga terletak pada unsur saling mengenal karena ketika pedagang mengetahui adanya sistem arisan pun diperoleh hasil ajakan temannya.

\subsection{Akuntansi Pinjaman Dana Bank Tithil di Pasar Singosari}

Berdasarkan apa yang telah diteliti peneliti pengakuan, pengukuran, penyajian, dan pengungkapan dalam pinjaman dana bank tithil di Pasar Singosari yang dilakukan oleh pedagang pada saat menerima dana dan membayar, rentenir pada saat memberikan pinjaman dana dan mendapatkan dana yang dikembalikan beserta bunga, kemudian bandar pada saat mendapatkan penerimaan angsuran tabungan dan komisi informan menggunakan mental accounting. Rospitadewi dan Efferin (2017) menyatakan bahwa Mental accounting merupakan pada pikiran manusia terdapat proses akuntansi seperti yang dilakukan dalam perusahaan yang meliputi pembukuan dan evaluasi pengambilan keputusan dalam melakukan konsumsi.

Pengakuan akuntansi yang dilakukan pedagang, rentenir, maupun bandar arisan menggunakan mental accounting. Perlakuan pengakuan akuntansi untuk pedagang ada yang menggunakan catatan kecil dalam kertas maupun buku kemudian ada juga hanya mengingat saja untuk dana yang diterima, bunga, dan angsuran harian yang harus dibayarkan. Perlakuan pengakuan akuntansi untuk rentenir dan bandar arisan dilakukan dengan cara dicatat dibuku masing-masing namun, dalam pencatatannya sendiri tidak sesuai dengan standar akuntansi. Pengakuan akuntansi yang dilakukan pedagang, rentenir, maupun bandar diakui pada saat tejadinya transaksi.

Pengukuran akuntansi yang dilakukan pedagang, rentenir, dan bandar diukur berdasarkan pada saat tatap muka dan berinteraksi untuk dibicarakan terkait pinjaman dana dan sistem arisan. Berikut pengukuran akuntansi dari pedagang, rentenir, dan bandar untuk perolehan pinjaman dana beserta bunga, total yang harus dibayarkan, dan total arisan beserta komisi untuk bandar yaitu: Mba Siti dengan rentenir ibu Rusdi, pinjaman pokok mba Siti sebesar Rp 3.000.000, biaya administrasi $\mathrm{Rp} 50.000$, bunga dari pinjaman pokok $15 \%$ yaitu $\mathrm{Rp} 450.000$, total pinjaman pokok dan bunga $\mathrm{Rp} 3.450 .000$, kemudian pembayarannya diberi waktu selama 115 hari dengan jumlah Rp 30.000.

Ibu Sumiati dengan rentenir ibu Rusdi, pinjaman pokok ibu Sumiati sebesar Rp 120.000 , bunga dari pinjaman pokok 25\% yaitu Rp 30.000, total pinjaman pokok dan bunga Rp 150.000, kemudian pembayarannya diberi waktu selama 15 hari dengan jumlah Rp 10.000. Ibu Tini dengan rentenir ibu Rusdi, pinjaman pokok ibu Tini sebesar Rp 150.000, bunga dari pinjaman pokok $20 \%$ yaitu Rp 30.000, total pinjaman pokok dan bunga $\mathrm{Rp} 180.000$, kemudian pembayarannya diberi waktu selama 18 hari dengan jumlah Rp 10.000. Pak Rahmat dengan rentenir mba Ratna, pinjaman pokok pak Rahmat sebesar Rp 500.000, bunga dari pinjaman pokok 20\% yaitu Rp 100.000, total pinjaman pokok dan bunga $R p$ 600.000, kemudian pembayarannya diberi waktu selama 24 hari dengan jumlah Rp 25.000.

Mba Nur dengan rentenir mba Ratna, pinjaman pokok mba Nur sebesar Rp 1.000.000, bunga dari pinjaman pokok 20\% yaitu Rp 200.000, total pinjaman pokok dan bunga Rp 1.200.000, kemudian pembayarannya diberi waktu selama 48 hari dengan jumlah Rp 25.000. Sistem arisan antara bu Nia, ibu Tantri, dan ibu Salama 
dengan bandar yang sama yaitu mba Nita, angsuran pembayaran arisan dilakukan setiap 10 hari sekali setiap bulan, untuk anggota yang mengikuti sebanyak 100 orang, angsuran arisan dibayar Rp 100.000 per hari, total arisan yang diperoleh yaitu 10 hari $\mathrm{x} 100$ orang $\mathrm{x} \operatorname{Rp} 100.000=\mathrm{Rp} 10.000 .000$, kemudian komisi yang didapat bandar arisan sebesar 20\% dari Rp 10.000.000 yaitu Rp 2.000.000.

Pengukuran akuntansi yang dilakukan oleh rentenir terhadap pedagang di Pasar Singosari untuk bank tithil pinjaman biasa hanya penambahan uang pokok dan bunga. Untuk pembayaran selanjutnya dibayar dengan cara angsuran sesuai per hari yang sudah disepakati. Elisa \& zuhroh (2017) berargumen bahwa bank tithil merupakan seseorang yang memberikan kredit jangka pendek dengan bunga 10\%$30 \%$ dan biasa disebut dengan pinjaman harian. Kemudian, bagi pedagang yang belum bisa membayar angsuran tersebut maka sesuai dengan kesepakatan antara pedagang dan rentenir akan berlaku.

Pengukuran akuntansi yang dilakukan oleh bandar terhadap pedagang di Pasar Singosari untuk bank tithil sistem arisan hanya pembayaran angsuran arisan. Untuk pembayaran selanjutnya dibayar dengan cara angsuran sesuai per hari yang sudah disepakati. Kemudian, bagi pedagang yang belum bisa membayar angsuran tersebut maka sesuai dengan kesepakatan bahwa tidak boleh menunggak dalam artian jika sehari tersebut tidak bisa bayar maka harus diganti dihari berikutnya. Arisan tersebut merupakan arisan harian yang setiap harinya akan ditagih oleh bandar berlaku setiap anggota yang mengikutinya. Hari diundi untuk menentukan siapa yang dapat, sudah diundi diawal.

Penyajian akuntansi yang dilakukan pedagang, rentenir, dan bandar tidak sesuai dengan standar akuntansi. Penyajian hanya mensyaratkan penyajian catatan peristiwa penarikan jaminana atau penunggakan pembayaran, pengaruh transaksi, dan kondisi lain yang sesuai dengan hari pada saat terjadinya transaksi. Pedagang, rentenir, maupun bandar tidak membuat laporan keuangan. Rentenir dan bandar hanya mencatat pos-pos yang dirasa perlu ada untuk pencatatan seperti nama, jumlah uang pinjaman, bunga, angsuran per hari, dan keterangan barang jaminan jika ada. Untuk pedagang hanya mencatat menurut kebebasan mereka, ada juga yang mengingatnya saja.

Pengungkapan akuntansi yang dilakukan pedagang, rentenir, dan bandar dilakukan sesuai kebebasan masing-masing saja tidak memiliki kebijakan. Pengungkapan informasi disajikan oleh rentenir dan bandar ditujukan kepada pedagang yang memakai jasa tersebut. Pengungkapan informasi tersebut tidak sesuai dengan standar akuntansi, hanya dibuat sesuai dengan kebebasan masingmasing saja seperti, pelaporan rinci transaksi dari angsuran pembayaran jika diperlukan pedagang untuk melihat angsurannya. Untuk pedagang tidak membuat pengungkapan untuk pengeluaran informasi.

\subsection{Alasan Pedagang Tertarik dengan Pinjaman Dana Bank Tithil di Pasar Singosari}

Seperti yang terjadi di lapangan dari 8 pedagang diantaranya 5 pedagang yang memakai jasa rentenir dan 3 pedagang memakai jasa arisan menyatakan alasan masing-masing tertarik ada yang untuk meminjam karena keperluan untuk modal, ada juga untuk kebutuhan sehari-hari, untuk biaya sekolah, dan untuk menutupi kurangan utang. Mereka membutuhkan dana dengan cara yang cepat dan mudah, meminjam dana kepada rentenir atau mengikuti arisan merupakan pilihan yang paling tepat. Apabila meminjam kepada lembaga keuangan pedagang menunggu proses yang lama dan pedagang merasa rumit jika harus meminjam dana ke lembaga keuangan.

Pinjaman dana yang lebih cepat dan mudah sangat membantu pedagang di Pasar Singosari. Pemberian pinjaman dana dari rentenir ini sangat disukai oleh 
pedagang meskipun ada yang tidak menyukai kegiatan tersebut. Mereka berpikir bahwa pinjaman dana yang diberikan rentenir sangat mudah syaratnya dengan bunga yang kecil namun, ada yang berpikir bahwa sangat berat jika harus meminjam dana kepada rentenir hanya untuk modal dan kebutuhan sehari-hari. Sistem arisan pun sangat membantu pedagang untuk mendapatkan dana karena, sistemnya seperti menabung dan pedagang tidak perlu memikirkan untuk pembayaran utang jika dengan sistem arisan.

Pembahasan akhir menurut peneliti yang dilakukan keduanya salah karena, dari rentenir sendiri memberikan pinjaman biasa sudah memberatkan untuk pedagang yang meminjamnya dengan alasan dibayar angsuran pinjaman setiap hari dan ada beberapa variasi bunga yang dibuat rentenir memberatkan pedagang. Untuk sistem arisan meskipun pedagang menyukainya karena seperti menabung tetapi, mereka masih ada yang keberatan karena dibayar setiap hari kemudian tidak diperbolehkan menunggak untuk pembayaran di hari tersebut. Bagi pedagang seharusnya bisa memilih tempat peminjaman uang yang lebih memudahkan pedagang dalam melihat risiko bunga dan pembayaran angsuran ketika dilakukannya pinjam meminjam dana atau pedagang dapat menabung di bank syariah sebagai bentuk dana kaget maupun untuk dana kebutuhan sehari-hari.

Bank tithil sudah menjadi budaya berkembang di pasar Singosari, kegiatan tersebut dilakoni oleh pedagang dan rentenir. Kegiatan bank tithil terjadi karena kepentingan ekonomi seperti, untuk perputaran modal, kebutuhan sehari-hari, bahkan sebagai penutup hutang sebelumnya. Selain itu, kegiatan bank tithil berada di pasar Singosari daerah yang terkenal akan 1000 pesantren dan masyarakatnya lebih banyak menonjol sikap religiusnya serta ekspresi beragamanya bagus. Perihal kegiatan bank tithil yang masih ada sampai saat ini bisa jadi ada pemahaman yang belum selesai di praktik Islam tersebut.

\section{SIMPULAN}

Bank Tithil khususnya di daerah pasar Singosari memiliki dua bentuk sistem yaitu sistem pinjaman biasa dan sistem arisan. Keduanya sudah menjadi budaya di daerah pasar Singosari, meskipun sikap religius di daerah tersebut menonjol, praktik tersebut tetap dilakukan antara pedagang dan rentenir. Akuntansi penyaluran modal bank tithil yang dibuat oleh pedagang, rentenir, dan bandar menggunakan mental accounting. Alasan pedagang tertarik dengan pinjaman dana bank tithil di Pasar Singosari karena pedagang di Pasar Singosari merasa pinjaman dana yang diberikan rentenir lebih murah karena, angsuran yang dibayar tidak dalam jumlah yang besar dengan persyaratan yang mudah dan cepat. Penelitian mengenai praktik akuntansi peminjaman dana dari bank titik memberikan kontribusi penelitian mengenai bentuk pencatatan transaksi akuntansi yang memiliki bentuk menyesuaikan dengan kondisi dimana akuntansi dipraktikkan. Untuk penelitian selanjutnya diharapkan dilakukan penelitian mengenai pasar tradisional untuk transaksi yang lain.

\section{REFERENSI}

Al Qur'anul Karim

Kamus Besar Bahasa Indonesia. [Online]. Tersedia di kbbi.kemendikbud.go.id/entri/religius. Diakses 9 Oktober 2020.

Aulia, D. (2017). Praktik Penyaluran Modal dari Rentenir ke Pedagang di Pasar Besar Palangkaraya (Skripsi tidak dipublikasikan). Jurusan Ekonomi Islam, Fakultas Ekonomi dan Bisnis Islam, Institut Agama Islam Negeri Palangkaraya.

Bank Indonesia. 1998. UU No.10 tahun 1998, Tentang Perubahan Terhadap UU No. 7 tahun 1992, Jakarta 
Belkuoi, Ahmed Riahi. (2006). Accounting Theory : Teori Akuntansi, Jakarta: Edisi Kelima, Salemba Empat.

Blackburn, K., Bose, N., \& Capasso, S. (2012). Tax evasion, the underground economy and financial development [Adobe Digital Editions version]. Doi: $10.1016 / j . j e b o .2012 .05 .019$

Blazy, R., Martel, J., \& Nigam, N. (2014). The choice between informal and formal restructuring: The case of French banks facing distressed SMEs [Adobe Digital Editions version]. Doi: 10.1016/j.jbankfin.2014.04.015

Burngin, Buerhan. (2001). Metodologi Penelitian Kualitatif, Jakarta: PT. Rajagrafindo Persada.

Bungin, Burhan. (2006). Metodologi Penelitian Kualitatif: Aktualisasi Metodologi ke Arah Ragam Varian Kontemporer, Jakarta: PT Raja Grafindo Persada.

Burngin, Buerhan. (2013). Metodologi Penelitian Sosial dan Ekonomi. Jakarta: Kencana.

Capasso, S., \& Jappelli, T. (2013). Financial development and the underground economy [Adobe Digital Editions version]. Doi: 10.1016/j.jdeveco.2012.10.005

Chaudry, Muhammad Sharif. (2014). Sistem Ekonomi Islam Prinsip Dasar, Jakarta: Kencana Prenadamedia Group.

Coulon, Alain. (2008). Etnometodologi. Jakarta: Penerbit Lengge bersama Kelompok Kajian Studi Kultural. Diterjemahkan dari L'ethnometodologi Paris: Presses Universitaires de France.

Cynthia P. (2014). Analisis Struktur Permodalan Usaha Mikro dan Kecil (UMK) dan Kaitannya dengan Perkembangan Usaha di Kabupaten Bogor. Skripsi Institut Pertanian Bogor.

Darmono Saputro, Siswandi. (2010). Banking and Non Banking, Jakarta: Lentera Ilmu Cendikia.

Dyckman, Thomas R, Roland E. Duker, Charles J. Davis. (2011). Akuntansi Intermediate, Edisi Ketiga, Jilid 1, Jakarta: Erlangga.

F. Erlina, http://eprints.uny.ac.id/8760/3/bab\%202\%20-08404244001.pdf, Tanggal: 09 November 2019 pukul 17.20

Frey BS, Schneider F (2001). Informal and Underground Economics. International Encyclopedia of the Social and Behavioral Sciences, Elsevier Science Ltd.

Gaspareniene, L., Remeikiene, R., \& Heikkila, M. (2017). Evaluation of the impact of shadow economy determinant [Adobe Digital Editions version]. Doi: $10.1016 /$ j.intele.2017.03.003

Houston, F, J. (1990). The Policy Implications of the Underground Economy [Adobe Digital Editions version]. Doi: 10.1016/0148-6195(90)90018-8.

Husein, Umar. (2000). Riset Pemasaran Dan Penilaian Konsumen. Jakarta: PT Gramedia Pustaka.

Ikhsan, Arfan, dkk. (2014). Pengantar Akuntansi, Medan: Cita Pustaka Media.

Kamayanti, Ari. (2017). Metodologi Penelitian Kualitatif Akuntansi. Cetakan 3. Jakarta Selatan: Yayasan Rumah Peneleh.

Kamayanti A. (2020). Metodologi Penelitian Kualitatif Akuntansi. Jakarta: Yayasan Rumah Peneleh.

Kasmir. (2007). Kewirausahaan. Jakarta: PT Raja Grafindo Persada.

Korwadi Siboro, Ilas. "Rentenir (Analisis terhadap Fungsi Pinjaman Berbunga dalam Masyarakat Rokan Hilir Kecamatan Bagan Sinembah Desa Bagan Batu)".Jurnal Ekonomi Vol. 2 No 2, Oktober 2015

Moleong, Lexy J. (2004). Metode Penelitian Kualitatif. Bandung : Rosda.

Mulyana, Ahmad. (2008). "Etnometodologi: Selayang Pandang". Media KOM (Online), Vol. 1 No.2 (http://isjd.pdii.lipi.go.id/admin/jurnal/12084651_19790139.pdf). 
Ningsih, D., \& Zuroh, I. (2010). Analisis Permintaan Kredit Investasi Pada Bank Swasta Nasional Di Jawa Timur. Ekonomi Pembangunan.

Pissarides, A, C., \& Weber, G. (1989). An Expenditure-Based Estimate of Britain's Black Economy [Adobe Digital Editions version]. Doi: 10.1016/00472727(89)90052-2

Rospitadewi, E., \& Efferin, S. (2017). Mental Accounting dan Ilusi Kebahagiaan: Memahami Pikiran dan Implikasinya Bagi Akuntansi.

Samuda, S. J. (2016). UNDERGROUND ECONOMY IN INDONESIA. Buletin Ekonomi Moneter Dan Perbankan, 19(1), 39-56. https://doi.org/10.21098/bemp.v19i1.599

Samuel, H., \& Nurina, S. (2015). Analysis of the Effect of Inflation, Interest Rates, and Exchange Rates on Gross Domestic Product (GDP) in Indonesia [Adobe Digital Editions version]. Diakses dari www.globalbizresearch.org.

Sari, N, N., \& Abdullah, D. (2019). Pendirian Bank tanpa Izin melakukan Usaha Perbankan (Shadow Banking) dalam Perspektif Hukum Islam. Jurnal Ilmiah Mahasiswa Jurusan Hukum Ekonomi Syariah.

Schneider, F., Enste, D.H., 2000. Shadow economies: sizes, causes and consequences. Journal of Economic Literature.

Sawitri, R. (1995). Aksesbilitas Kredit Pedesaan (Studi Kasus Pada Rumah Tangga Pedesaan Di Desa Kauman Kidul Dan Desa Bugel Kecamatan Sidoarjo Kodya Salatiga.

Subagyo, Joko. (2004). Metode penelitian Dalam Teori dan Praktik, Jakarta: PT Renika Cipta.

Suharsaputra, Uhar. (2012). Metodologi Penelitian Kuantitatif, Kualitatif, dan Tindakan. Bandung: PT Revika Aditama.

Supramono dan Damayanti, Theresia Woro. (2013). Identifikasi Fenomena Mental accounting: Antara Evaluasi Segregasi dan Integrasi. Jurnal Bina Akuntansi Vol. 1 No. 1.

Suwardjono. (2014). Teori Akuntansi Perekayasaan Pelaporan Keuangan, Edisi Ketiga, Yogyakarta: BPFE-YOGYAKARTA.

Thaler, R. H. (1999). Mental Accounting Matters. Journal of Behavioral Decision Making, 12(3), 183-206. https://doi.org/10.1002/ $\quad$ (SICI) 10990771(199909)12:3<183::AIDBDM318>3.0.CO;2-F

Wijaya, Faried dan Soetatwo Hadiwigono. (1995). Lembaga-Lembaga Keuangan dan Bank. Yogyakarta: BPFE Yogyakarta. 
Halaman ini sengaja dikosongkan 